\title{
Amylin-induced in vivo insulin resistance in conscious rats: the liver is more sensitive to amylin than peripheral tissues
}

\author{
S.J.Koopmans ${ }^{1}$, A.D.M.van Mansfeld ${ }^{2}$, H.S.Jansz ${ }^{2}$, H.M.J.Krans ${ }^{1}$, J.K. Radder ${ }^{1}$, M.Frölich ${ }^{1}$, S.F. de Boer ${ }^{3}$, \\ D. K. Kreutter ${ }^{4}$, G.C.Andrews ${ }^{4}$ and J.A.Maassen ${ }^{5}$ \\ ${ }^{1}$ Department of Endocrinology and Metabolic Diseases, University Hospital, Leiden, \\ ${ }^{2}$ Laboratory for Physiological Chemistry and ${ }^{3}$ Department of Psychophysiology, State University, Utrecht, The Netherlands \\ ${ }^{4}$ Pfizer Central Research, Groton, Connecticut, USA \\ 5 Department of Medical Biochemistry, Sylvius Laboratories, Leiden, The Netherlands
}

\begin{abstract}
Summary. Amylin is a polypeptide of 37 amino acids, predominantly synthesized in pancreatic Beta cells. The peptide was suggested to be dysregulated in Type 2 (non-insulin-dependent) diabetes mellitus and it antagonized certain actions of insulin in vitro in rat muscle. This led to speculation that amylin is involved in the pathogenesis of Type 2 diabetes. We have examined the in vivo effects of rat amylin, amidated at the carboxy-terminus, on insulin-mediated carbohydrate metabolism in conscious rats, using the hyperinsulinaemic $( \pm 1 \mathrm{nmol} / \mathrm{l})$ euglycaemic $(6 \mathrm{mmol} / \mathrm{l})$ clamp technique combined with $\left[3-{ }^{3} \mathrm{H}\right]$-glucose infusion. Basal plasma amylin levels were $\leq 75 \mathrm{pmol} / \mathrm{l}$. Applied amylin levels of $220 \pm 75 \mathrm{pmol} / 1$ (infusion rate of $12.5 \mathrm{pmol} / \mathrm{min}$ ) antagonized only the insulin action on liver, resulting in a $100 \%$ increase of hepatic glucose output. Amylin levels of $4750 \pm 750 \mathrm{pmol} / 1$ (infusion rate of $125 \mathrm{pmol} / \mathrm{min}$ ) induced a $250 \%$ increase of
\end{abstract}

insulin-inhibited hepatic glucose output and, in addition, a $30 \%$ decrease of insulin-stimulated peripheral glucose uptake. Amylin did not affect: 1) the metabolic clearance rate of insulin, 2) the levels of plasma glucagon, epinephrine, norepinephrine, and corticosterone, 3 ) in vitro insulin binding and insulin-stimulated receptor autophosphorylation. This suggests that amylin antagonizes insulin action via binding to a yet unknown receptor. In conclusion: amylin causes in vivo insulin resistance and the liver seems the predominant organ regulated by this hormone. The in vivo effects of amylin mimic the pathophysiological abnormalities of insulin action in Type 2 diabetes.

Key words: Amylin, islet amyloid polypeptide, glucose production, glucose uptake, in vivo, clamp, counterregulatory hormones, insulin action, insulin receptor, diabetes mellitus.
A central characteristic of Type 2 (non-insulin-dependent) diabetes mellitus is insulin resistance. The underlying mechanism for this is unclear. Recently, a pancreatic polypeptide of 37 amino acids named amylin, also called islet amyloid polypeptide (IAPP) [1,2] or diabetes associated peptide (DAP) [3], was suggested to be dysregulated in Type 2 diabetes [3]. In vitro studies [4,5] using isolated rat muscle showed that amylin antagonized certain actions of insulin. This led to the speculation that amylin could play a role in the pathogenesis of Type 2 diabetes. Surprisingly, amylin did not inhibit insulin action in adipose tissue [5]. For hepatocytes no data are available yet.

Considering the in vitro data, it is important to know whether amylin can induce insulin resistance in vivo, as seen in Type 2 diabetes. Recently, the in vivo action of amylin on insulin-mediated glucose disposal was investigated by several groups. A study in man [6], using the intravenous glucose tolerance test, suggested that amylin was not an important factor for the induction of insulin resistance. However, two other studies in dogs and rats, using the hyperinsulinaemic euglycaemic clamp tech- nique, indicated that amylin caused peripheral $[7,8]$ and hepatic insulin resistance [8]. In addition, Young et al. [9] have shown that in rats, amylin stimulates glycogenolysis and inhibits glucose uptake in vivo.

In the present study we have examined the in vivo effects of specific rat amidated-amylin on insulin-mediated carbohydrate metabolism in conscious rats, using the hyperinsulinaemic euglycaemic clamp technique combined with $\left[3-{ }^{3} \mathrm{H}\right]$-glucose infusion. This enabled us:

1. To discriminate between in vivo hepatic glucose production and peripheral tissue glucose uptake. The use of two different amylin infusion rates during the clamp could give us an indication about the sensitivity of glucose production and glucose uptake for amylin.

2 . To study the effect of amylin on insulin-counterregulatory hormones in a rat model without anaesthesia-induced disturbances of the central nervous system.

Additionally we performed in vitro insulin receptor studies to elucidate whether possible amylin effects on insulin ac- 
tion were directed towards interference with insulin binding and insulin-stimulated receptor autophosphorylation.

\section{Materials and methods}

\section{Synthesis of rat amylin}

In this study we have used synthetic rat amylin, having a disulphide bond between the two cystein residues and an amide group at the carboxy-terminus. It was found that both features are necessary for full biological activity [10]. Amylin was synthesized on an Applied Biosystems Peptide Synthesizer and purified by reverse phase HPLC to a purity of $95 \%$. The correct sequence of the peptide was confirmed by protein sequencing on an Applied Biosystems Gas Phase Sequencer. Amylin concentration was determined by amino acid analysis of the stock solution.

\section{Experimental animals and housing}

Male Wistar rats ( $\pm 350 \mathrm{~g}$ ) with free access to complete laboratory rat chow (Hope Farms b.v. Woerden, The Netherlands) and water were individually housed in plexiglass metabolic cages $(21 \times 22 \times 26 \mathrm{~cm})$ at a constant temperature $\left(23^{\circ} \mathrm{C}\right)$ and a fixed $12 \mathrm{~h} \mathrm{light} / 12 \mathrm{~h}$ dark cycle (lights on at 07.00 hours). Rats were acquired and used in compliance with the Dutch law and institutional regulations.

\section{Surgical procedure}

Under complete ether anaesthesia, rats were provided with two sterile silicon cannulae (Silastic, medical-grade tubing, cat. no.602135 , internal diameter $0.051 \mathrm{~cm}$; external diameter $0.094 \mathrm{~cm}$ and cat. no. 602-105, internal diameter $0.031 \mathrm{~cm}$; external diameter $0.064 \mathrm{~cm}$, Dow Corning Corporation, medical products, Midland, Mich., USA): the large cannula into the right jugular vein for the infusion of fluids and the smaller into the left carotid artery for blood sampling. The tip of the jugular cannula was situated at the entrance of the right atrium and the tip of the carotid cannula at the transition of the carotid artery and aortic arch. Surgical manipulations were performed according to the method of Steffens [11] and both cannulae were attached to $90^{\circ}$-bended steel tubings which were manufactured from 20 gauge $* 1.5$ needles (Microlance, Becton Dickinson, Dublin, Ireland). The two steel tubings were fixed on top of the rat skulls by means of four screws (4*1 mm) and dental cement (Simplex rapid, Austenal, Dental Products Lid., Harrow, UK). The venous catheter was filled with an $0.9 \% \mathrm{NaCl}$ solution containing $0.2 \mathrm{mg} \cdot \mathrm{ml}^{-1}$ ticarcillin (Ticarpen, Beecham Farma, Amstelveen, The Netherlands), $500 \mathrm{IU} \cdot \mathrm{ml}^{-1}$ heparin (Thromboliquine, Organon Teknika, Oss, The Netherlands), and $0.55 \mathrm{~g} \cdot \mathrm{ml}^{-1}$ polyvinylpyrrolidone (p.v.p., M.W. $=25000$, Merck). The arterial catheter was filled with an $0.9 \%$ $\mathrm{NaCl}$ solution containing $0.2 \mathrm{mg} \cdot \mathrm{ml}^{-1}$ ticarcillin, $500 \mathrm{IU} \cdot \mathrm{ml}^{-1}$ heparin and $0.6 \mathrm{~g} \cdot \mathrm{ml}^{-1} \mathrm{p}$.v.p.

When the dental cement had hardened, the venous line was connected to a double lumen tubing (polyethylene, internal diameter $0.041 \mathrm{~cm}$, external diameter $0.102 \mathrm{~cm}$, Talas, Ommen, The Netherlands) by means of a piece of polyethylene tubing (internal diameter $0.076 \mathrm{~cm}$, external diameter $0.147 \mathrm{~cm}$, Rubber, Hilversum, The Netherlands). The double lumen tubing was connected to a double lumen swivel [12] allowing separate fluid infusions (i.e. an insulin and $\left[3-{ }^{3} \mathrm{H}\right]$-glucose solution via one channel and a glucose solution through the other channel) in the conscious, undisturbed, freely moving rat. Doing so, insulin and glucose could be kept separate until reaching the rats skull allowing a low infusion rate (the insulin and $\left[3-{ }^{3} \mathrm{H}\right]$-glucose solution infusion rate was $400 \mu \mathrm{l} \cdot \mathrm{h}^{-1}$; the glucose infusion rate was variable). The venous double lumen tubing and the swivel were filled with a $0.9 \% \mathrm{NaCl}$ solution and sealed. The carotid line was connected to a polyethylene tubing (internal diameter $0.076 \mathrm{~cm}$, external diameter $0.147 \mathrm{~cm}$, Rubber, Hilversum, The Netherlands), filled with the arterial $0.9 \% \mathrm{NaCl}$ solution with p.v.p., sealed and attached aside to the lower, rotating part of the swivel. Both venous double lumen tubing and arterial blood sampling tubing were protected by an outer transparent, flexible Tygon tubing (internal diameter $0.406 \mathrm{~cm}$, external diameter $0.711 \mathrm{~cm}$ ). The rat, permanently attached to the swivel, was placed in a metabolic cage and the swivel was connected to a contra weight. After surgery, the rats were allowed to recover for at least one week before the clamp experiments were performed. During this period the arterial catheter was aspirated every other day to maintain catheter patency and to adapt the rats to the clamp and blood sampling procedure. Within a week after surgery the rats reached their preoperative weight and were used for the clamp studies.

\section{The hyperinsulinaemic euglycaemic clamp technique}

The clamp was started at \pm 11.00 hours, after $18 \mathrm{~h}$ of food deprivation. One hour before clamping the venous and arterial cannulae were aspirated, the venous line was filled with a $0.9 \% \mathrm{NaCl}$ solution and the arterial line with a $0.9 \% \mathrm{NaCl}$ solution containing $5 \mathrm{IU} \cdot \mathrm{ml}^{-1}$ heparin. The double lumen swivel, allowing separate fluid infusions, was connected to two peristaltic pumps (Watson Marlow 202U/AA, Falmouth, UK). One venous line was used for the infusion of a $20 \%$ glucose solution at a variable rate and the other line was used for infusion of a mixture of $\left[3-{ }^{3} \mathrm{H}\right]$-glucose (Du Pont-NEN, Boston, Mass., USA, specific activity $13.5 \mathrm{Ci} \cdot \mathrm{mmol}^{-1}$ ), insulin (Actrapid porcine insulin, Novo, Copenhagen, Denmark), amylin and $1 \%$ rat plasma in insulin dilution medium (Novo) at a constant rate $\left(400 \mu \mathrm{l} \cdot \mathrm{h}^{-1}\right)$. The arterial blood sampling tubing allowed frequent sampling and repletion of blood loss by means of fresh pre-warmed whole blood obtained from littermates. The transfusion blood contained $3 \mathrm{mg} \cdot \mathrm{ml}^{-1}$ citrate to prevent clotting. Citrate was chosen instead of heparin to avoid possible activation of lipoprotein lipase during the clamp.

At the start of the euglycaemic clamp, a bolus $(3 \mu \mathrm{Ci})$-continuous $\left(0.05 \mu \mathrm{Ci} \cdot \mathrm{min}^{-1}\right)$ infusion of $\left[3-{ }^{3} \mathrm{H}\right]$-glucose and a bolus $(30 \mathrm{pmol})$ continuous $\left(6 \mathrm{pmol} \cdot \mathrm{min}^{-1}\right)$ infusion of insulin was initiated and contimued throughout the 220 min study. During the $220 \mathrm{~min}$ clamp blood $(40 \mu \mathrm{l})$ was collected at 5-10 min intervals for fast determination of plasma glucose. So the variable $20 \%$ glucose infusion could be adjusted to reach and maintain plasma glucose at the desired level of $6 \mathrm{mmol} / \mathrm{l}$. At $t=100 \mathrm{~min}$ an amylin infusion was started of 12.5 or $125 \mathrm{pmol} / \mathrm{min}$ and continued throughout the study. At $t=80,90,100$, 200,210 , and $220 \mathrm{~min}$ (steady-state) blood samples were collected for determination of plasma glucose, insulin and specific activity of tritiated glucose.

At $t=60$ and $160 \mathrm{~min}$, blood samples for determination of amylin, glucagon, epinephrine, norepinephrine, and corticosterone were collected.

At the end of the $125 \mathrm{pmol} / \mathrm{min}$ amylin intusion clamp, the amylin infusion was stopped and at $t=0,2,4,8,10,16,22$, and $30 \mathrm{~min}$ blood samples $(200 \mu \mathrm{l})$ were collected for determination of the decay curve of plasma amylin.

A separate set of 220 min lasting control clamp experiments without amylin infusion were performed to investigate the self-amplifying effect of long-term clamping on insulin-mediated glucose metabolism, since it is known that glucose metabolism is not constant during a 220 min study [13]. The experimental procedure was identical to the amylin fusion clamps and at $t=80,90,100,200,210$ and 220 min blood samples were collected for determination of plasma glucose, insulin and specific activity of tritiated glucose.

\section{Chemical determinations}

Blood samples $(40 \mu \mathrm{l})$ for ghucose determinations were collected in heparinized tubes and immediately centrifuged in a microcentrifuge (Beckman Instruments, Palo Alto, Calif., USA). Plasma glucose was 

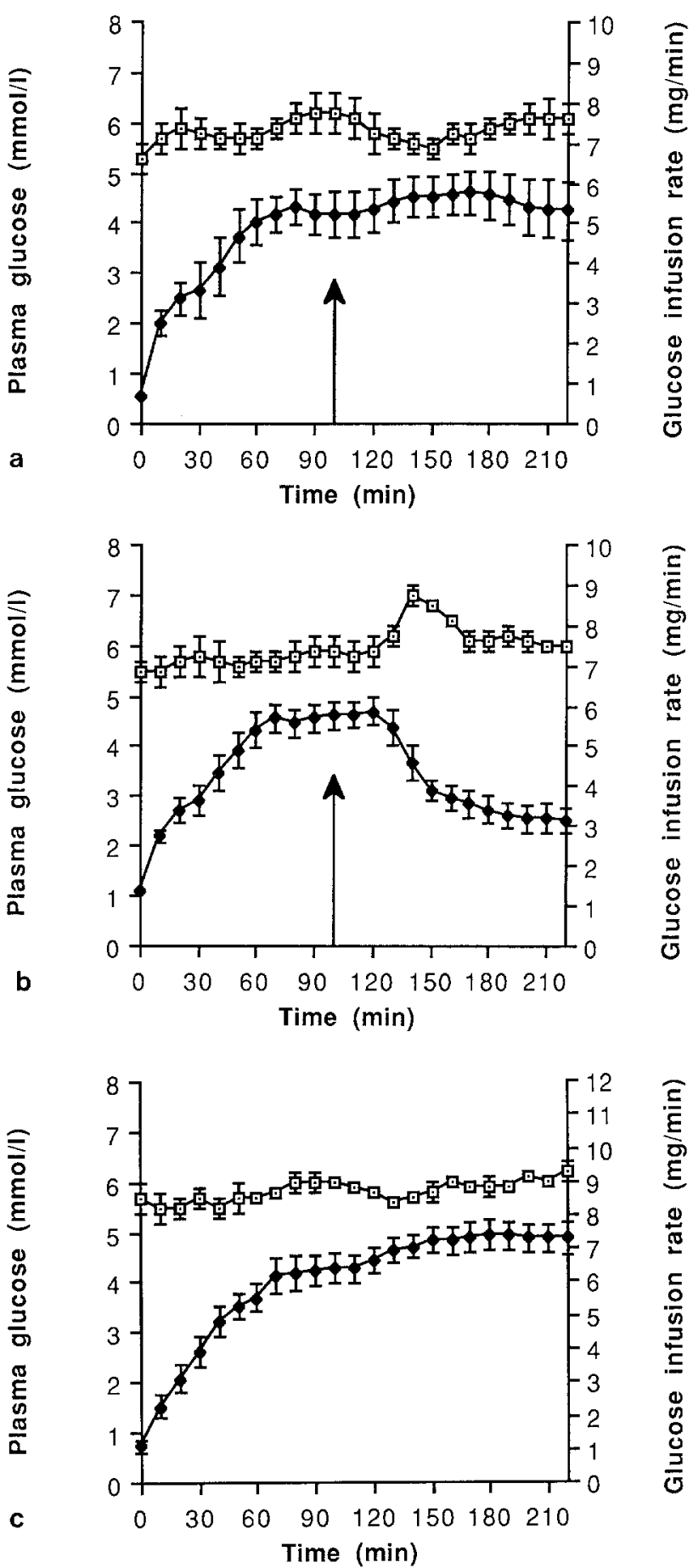

Fig. 1 a-c. Dynamics of plasma glucose levels and glucose infusion rate during $220 \mathrm{~min}$ of hyperinsulinaemic ( $\pm 1 \mathrm{nmol} / \mathrm{l}$ ) euglycaemic $(6 \mathrm{mmol} / \mathrm{l})$ clamping of conscious, unrestrained rats. The arrow at $t=100 \mathrm{~min}$ indicates the start of a continuous infusion of amylin at a rate of $12.5 \mathrm{pmol} / \mathrm{min}$ (a) or $125 \mathrm{pmol} / \mathrm{min}(\mathbf{b})$. The control clamp without amylin infusion is shown in $\mathbf{c}$. The data are averaged values of clamps on 5 (a), 6 (b) or 6 rats (c). Mean \pm SEM is indicated. Plasma glucose $(-\bullet-)$, glucose infusion rate $(\longrightarrow-)$

measured by the glucose oxidase method (Glucose Analyser II, Beckman Instruments). Blood samples $(150 \mu \mathrm{l})$ for insulin were transferred to chilled $\left(0^{\circ} \mathrm{C}\right)$ heparinized tubes, centrifuged within $5 \mathrm{~min}$, plasma was removed and stored at $-80^{\circ} \mathrm{C}$ until assay. Insulin was measured in duplicate by a specific rat radioimmunoassay as described previously [14], rendering identical standard curves for rat and porcine insulin. Intra- and inter-assay variations of the insulin assay were $6.8 \%$ and $8.1 \%$, respectively. Samples for the determination of catecholamines (CA) and corticosterone (CS) $(250 \mu \mathrm{l})$ were transferred to chilled $\left(0^{\circ} \mathrm{C}\right)$ heparinized tubes, containing $10 \mu \mathrm{l}$ of a solution of $25 \mathrm{mg} / \mathrm{ml}$ disodium EDTA in order to prevent CA degradation and centrifuged immediately. Plasma was removed and stored at $-80^{\circ} \mathrm{C}$ until assay. The concentrations of norepinephrine and epinephrine were measured in duplicate in $20 \mu \mathrm{l}$ perchloric aciddeproteinized plasma according to a radioenzymatic COMT-procedure [15]. The CAs were converted into their $\left[{ }^{3} \mathrm{H}\right]$-methoxy derivatives by incubation with S-adenosyl-L-[methyl- $\left.{ }^{3} \mathrm{H}\right]$ methionine $\left(80 \mathrm{Ci} \cdot \mathrm{mmol}^{-1}\right.$; NEN Chemicals) in the presence of catechol-Omethyltransferase. Labelled products were isolated by organic extraction and paper chromatography. After elution of labelled products, activity was counted in a liquid scintillation analyser (Philips, Eindhoven, The Netherlands). The intra- and interassay variabilities were less than $10 \%$ and $15 \%$, respectively. Plasma CS concentrations were determined in duplicate according to a competitive protein-binding method [16]. CS was extracted with dichloromethane from $25 \mu \mathrm{l}$ samples of plasma and the dry residue was incubated with a corticosteroid-binding globulin tracer solution $[0.1 \%$ plasma from adrenalectomized female rats containing $\left[1,2-{ }^{3} \mathrm{H}\right]$-corticosterone (40-50 Ci. $\mathrm{mmol}^{-1}$; NEN Chemicals) as tracer]. Unbound steroid was removed using dextran-coated charcoal. Standard CS was supplied by Sigma. The intra- and interassay coefficients of variation were less than $10 \%$.

Blood samples $(400 \mu \mathrm{l})$ for glucagon and amylin were transferred to chilled $\left(0^{\circ} \mathrm{C}\right)$ heparinized tubes, supplemented with $5 \%$ trasylol $\left(10,000 \mathrm{KIE} \cdot \mathrm{ml}^{-1}\right.$, Bayer, Leverkusen, FRG) in order to prevent hormone degradation and centrifuged immediately. Plasma was removed and stored at $-80^{\circ} \mathrm{C}$ until assay. Plasma glucagon concentrations were determined in duplo by a radioimmunoassay (Daiichi, Tokyo, Japan). The interassay coefficient of variation was $8.6 \%$. Plasma amylin was determined by radioimmunoassay using a kit from Peninsula Laboratories (Belmont, Calif., USA). The assay uses [ $\left.{ }^{125} \mathrm{I}\right]$-amylin and a double antibody precipitation. No interfering substances in plasma were found and using known concentrations of pure, synthetic amylin, the assay proved to be perfectly quantitative and linear for amylin concentrations between 75 and $400 \mathrm{pmol} / \mathrm{l}$. No cross reactivity with CGRP and insulin was found. The intraassay variation averaged $8 \%$ and the interassay variation was between $5 \%$ and $35 \%$. It is difficult to indicate how much of the interassay variation is due to the animals and how much is due to the assay. We have never run the same sample in repeated assays. Therefore, the $35 \%$ value represents a maximal variation. Plasma for $\left[3-{ }^{3} \mathrm{H}\right]$-glucose radioactivity $(150 \mu \mathrm{l})$ was deproteinized by barium hydroxide-zinc sulphate (Somogyi procedure), the supernatant was evaporated to dryness at $60^{\circ} \mathrm{C}$ to eliminate tritiated water and counted for $10 \mathrm{~min}$ in a beta scintillation counter (LKB, Woerden, The Netherlands).

\section{Calculations}

The rate of exogenous infused glucose to maintain euglycaemia during the steady-state period (from $t=80-100 \mathrm{~min}$ and 200-220 $\mathrm{min}$ ) was used for the assessment of insulin action. All calculations were carried out in this period when the total amount of glucose taken up by all tissues of the body is equal to the input of glucose into the body. During this steady-state, when the rate of glucose appearance ( $\mathrm{Ra})$ is equal to the rate of glucose disappearance (Rd), the glucose turnover rate $(=\mathrm{Ra}=\mathrm{Rd}$ in $\mathrm{mg} / \mathrm{min})$ was calculated by dividing the $\left[3-{ }^{3} \mathrm{H}\right]$-glucose infusion rate $\left(\mathrm{dpm} \cdot \mathrm{min}^{-1}\right)$ by the steady-state value of glucose specific activity $\left(\mathrm{dpm} \cdot \mathrm{mg}^{-1}\right)$. Under these conditions, the glucose turnover rate is equal to the sum of the rates of exogenous infused glucose and of hepatic glucose production (HGP). From this equation the rate of $\mathrm{HGP}$ can be calculated. Since urinary glucose loss was not present, peripheral glucose uptake $(\mathrm{PGU})=$ glucose turnover rate $=$ exogenous glucose infusion rate + rate of HGP. 
Table 1. Characteristics of rats during the hyperinsulinaemic euglycaemic clamp

\begin{tabular}{|c|c|c|c|c|c|c|}
\hline & \multicolumn{6}{|c|}{ Amylin infusion rates ( $\mathrm{pmol} / \mathrm{min})$} \\
\hline & 0 & 0 & 0 & 12.5 & 0 & 125 \\
\hline $\begin{array}{l}\text { Steady-state levels of: } \\
\text { Amylin (pmol/1) } \\
\text { Insulin (nmol/l) }\end{array}$ & $\begin{array}{l}\text { ND } \\
1.7 \pm 0.2\end{array}$ & $\begin{array}{l}\text { ND } \\
1.7 \pm 0.2\end{array}$ & $\begin{array}{l}\leq 75^{\mathrm{a}} \\
1.1 \pm 0.1\end{array}$ & $\begin{array}{l}220 \pm 75 \\
1.1 \pm 0.1\end{array}$ & $\begin{array}{l}\leq 75^{\mathrm{a}} \\
1.0 \pm 0.1\end{array}$ & $\begin{array}{c}4750 \pm 750 \\
1.0 \pm 0.1\end{array}$ \\
\hline Hepatic glucose production ( $\mathrm{mg} / \mathrm{min})$ & $0.2 \pm 0.2$ & $-0.1 \pm 0.2^{d}$ & $0.7 \pm 0.3$ & $1.4 \pm 0.4^{c}$ & $0.5 \pm 0.2$ & $1.7 \pm 0.3^{6}$ \\
\hline Glucagon (pmol/l) & ND & $\mathrm{ND}$ & ND & $\mathrm{ND}$ & $10.9 \pm 1.2$ & $8.6 \pm 0.6$ \\
\hline Epinephrine (nmol/l) & ND & ND & ND & ND & $1.6 \pm 0.2$ & $1.6 \pm 0.2$ \\
\hline Norepinephrine (nmol/l) & ND & ND & ND & ND & $3.0 \pm 0.3$ & $2.5 \pm 0.3$ \\
\hline Corticosterone $(\mathrm{nmol} / \mathrm{l})$ & ND & ND & ND & ND & $857 \pm 147$ & $779 \pm 139$ \\
\hline
\end{tabular}

The effects of amylin infusion rates of $0,12.5$ and $125 \mathrm{pmol} / \mathrm{min}$ during $220 \mathrm{~min}$ of hyperinsulinaemic euglycaemic clamping in 6,5 and 6 conscious rats, respectively. From $t=0$ to $t=100 \mathrm{~min}$, no amylin was infused and steady-state glucose disposal was quantitated at $t=80,90$ and $100 \mathrm{~min}$. From $t=100$ to $220 \mathrm{~min}$, amylin was infused at a rate of $0,12.5$ or $125 \mathrm{pmol} / \mathrm{min}$ and steady-state glucose disposal was quantitated at $t=200,210$ and $220 \mathrm{~min}$. During the entire $220 \mathrm{~min}$ clamp, the insulin infusion rate was $6 \mathrm{pmol} / \mathrm{min}$ and plasma glucose was kept at $6 \mathrm{mmol} / \mathrm{l}$.

\section{Insulin receptor studies}

Insulin binding was to $10^{6}$ RAT-1 cells (a rat fibroblast cell line) at confluency. Concentration of $\left[{ }^{125} \mathrm{I}\right]$-insulin was $30 \mathrm{pmol} / \mathrm{l}$. Amylin was added one hour prior to addition of $\left[{ }^{125} \mathrm{I}\right]$-insulin. Non-specific binding of insulin, measured by addition of $1 \mu \mathrm{mol} / \mathrm{l}$ non-radioactive insulin, was subtracted. Experimental conditions were as described [17]. For insulin receptor autophosphorylation studies, the insulin receptor was partially purified from RAT-1 cells and rat liver by isolation of the glycoprotein fraction by chromatography on wheatgerm agglutinin-Sepharose (Pharmacia, Woerden, The Netherlands). Autophosphorylation on $10 \mu \mathrm{g}$ of glycoprotein was performed with $\left[\gamma^{32} \mathrm{P}\right]-\mathrm{ATP}$ in the absence and presence of $10 \mathrm{nmol} / 1$ insulin, each experiment both with and without $1 \mu \mathrm{mol} / \mathrm{l}$ amylin. Amylin was added one hour prior to addition of insulin. Experimental conditions for quantitation of insulin-stimulated $\beta$-chain autophosphorylation were as described [18].

\section{Statistical analysis}

Data are expressed as mean \pm SEM. Within subject comparisons were made using the paired Student's $t$-test. The criterion of significance was set at $p<0.05$.

\section{Results}

A low $(12.5 \mathrm{pmol} / \mathrm{min})$ and high $(125 \mathrm{pmol} / \mathrm{min})$ amylin infusion rate was used to examine the effect on peripheral glucose uptake and hepatic glucose production. Figure 1 shows the profiles of plasma glucose and glucose infusion rate during the clamp experiments. Prior to the addition of amylin, during the first $60 \mathrm{~min}$, the glucose infusion rate is increased until steady-state is reached. Then, infusion of amylin is started as indicated by the arrow in Figure $1 \mathrm{a}$ and $\mathrm{b}$. Panel a represents the mean data of clamps on five rats with a low infusion rate of
${ }^{2}$ Basal amylin levels, in $18 \mathrm{~h}$ fasted rats, were below the detection limit of the RIA, except in two rats having a plasma amylin level of $75 \mathrm{pmol} / \mathrm{l}$. Data were expressed as mean \pm SEM.

${ }^{b} p<0.005 ;{ }^{c} p<0.01 ;{ }^{d} p<0.05$, as compared to the corresponding $0 \mathrm{pmol} / \mathrm{min}$ amylin infusions.

$\mathrm{ND}=$ not determined

amylin $(12.5 \mathrm{pmol} / \mathrm{min})$, panel b shows the data of six rats having a high infusion rate of $125 \mathrm{pmol} / \mathrm{min}$, and panel c shows the control infusion experiment in six rats without infusion of amylin. After a lag period of approximately $30 \mathrm{~min}$, plasma glucose levels rose in response to the high infusion rate of amylin. To maintain normoglycaemia, the rate of glucose infusion had to be decreased (Fig. 1 b). With a ten-fold lower infusion rate of amylin, no clear effect was observed on the plasma glucose level and glucose infusion rate (Fig.1a). However, when the in vivo changes of specific activity of plasma $\left[3-{ }^{3} \mathrm{H}\right]$-glucose were measured, both the low $(12.5 \mathrm{pmol} / \mathrm{min})$ and the high $(125 \mathrm{pmol} / \mathrm{min})$ amylin infusion included changes in specific activity of $\left[3-{ }^{3} \mathrm{H}\right]$-glucose. From the data of Figure 1 (glucose infusion rate) and the data of glucose turnover as calculated from glucose specific activity, both hepatic glucose production and peripheral glucose uptake were quantitated as shown in Table 1 . The infusion of $125 \mathrm{pmol} / \mathrm{min}$ amylin decreased peripheral glucose uptake and increased hepatic glucose production. During the low $(12.5 \mathrm{pmol} / \mathrm{min})$ infusion rate of amylin only the effect on liver was evident. The $10 \%$ increase in peripheral glucose uptake from 6.0 to $6.6 \mathrm{mg} \cdot \mathrm{min}^{-1}$ is a typical effect of long-term clamping [13], which we also observe during the control infusion experiment (an increase of $12 \%$, from 6.5 to $7.3 \mathrm{mg} \cdot \mathrm{min}^{-1}$ ), and does not result from amylin action. When this increase is corrected for, it can be calculated that an infusion rate of $125 \mathrm{pmol} / \mathrm{min}$ of amylin inhibited peripheral glucose uptake by $30 \%$.

The plasma amylin concentrations in $18 \mathrm{~h}$ fasted rats, before and after one hour of infusion with amylin are shown in Table 1. To get an indication of plasma amylin levels in rats, kept under ad libitum fed conditions (i.e. not fasted overnight for $18 \mathrm{~h}$ ), we found amylin to be $60 \pm 20 \mathrm{pmol} / \mathrm{l}$, as measured in 21 rats. 


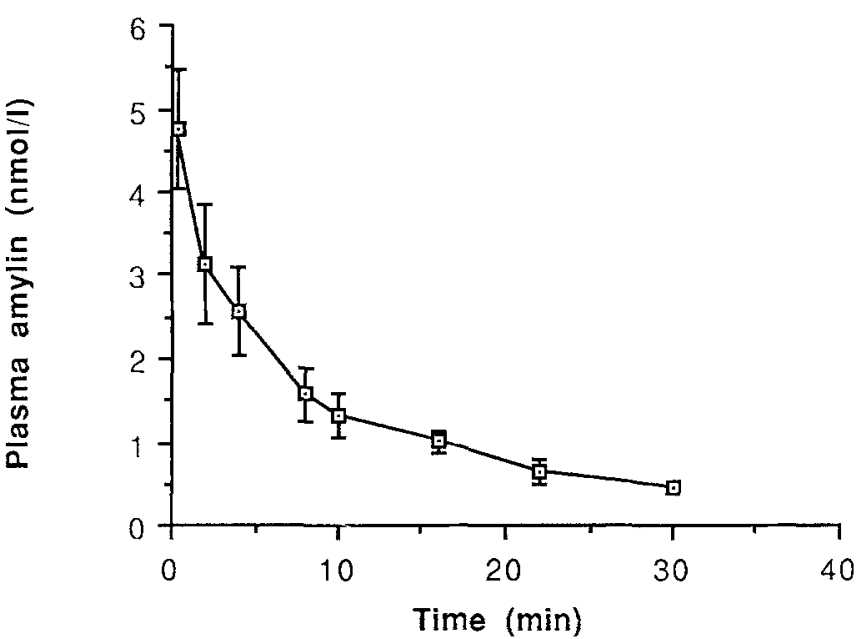

Fig. 2. The plasma amylin disappearance curve after cessation of the amylin infusion of $125 \mathrm{pmol} / \mathrm{min}$ in 3 rats. Data are expressed as mean $\pm S E M$

The metabolic clearance rate of amylin at an infusion rate of 12.5 and $125 \mathrm{pmol} / \mathrm{min}$ was $55 \pm 17 \mathrm{ml} \cdot \mathrm{min}^{-1}$ and $26 \pm 5 \mathrm{ml} \cdot \mathrm{min}^{-1}$, respectively. For insulin, at an infusion rate of $6 \mathrm{pmol} / \mathrm{min}$, the metabolic clearance rate averaged $6 \mathrm{ml} \cdot \mathrm{min}^{-1}$. To study the effects of amylin on insulincounterregulatory hormones, plasma levels of these hormones were determined before and during infusion with $125 \mathrm{pmol} \cdot \mathrm{min}^{-1}$ amylin. No increase in concentration of counterregulatory hormones was seen. Also, the metabolic clearance rate of insulin was unaffected during amylin infusion.

Figure 2 shows the plasma amylin disappearance curve after cessation of the amylin infusion of $125 \mathrm{pmol} / \mathrm{min}$. After $\log$ transformation the data seem to fit a two or more compartmental model. The half-life of amylin would be $5.5 \pm 0.2 \mathrm{~min}$ during the first $10 \mathrm{~min}$ after cessation of the amylin infusion. Thereafter, (from $t=10$ $30 \mathrm{~min}$ ) the half-life would be $14.8 \pm 3.3 \mathrm{~min}$. The overall half-life was calculated to be $9.4 \pm 1.0 \mathrm{~min}$.

We have examined whether amylin interferes with binding of insulin to its receptor and the subsequent increase in receptor autophosphorylation. For that, the effect was studied of $1 \mu \mathrm{mol} / 1$ amylin on $\left[{ }^{125} \mathrm{I}\right]$-insulin binding to RAT-1 cells and insulin-stimulated $\beta$-chain autophosphorylation using partially purified insulin receptors from RAT-1 cells and rat liver. No effect of amylin was detected in these experiments. At amylin concentrations of 0 and $\left.1 \mu \mathrm{mol} / \mathrm{l},{ }^{[25} \mathrm{I}\right]$-insulin binding was $10.4 \pm 0.4$ and $10.3 \pm 0.6\left(* 10^{-17} \mathrm{~mol} / 10^{6}\right.$ cells $)(n=4)$ and insulin was able to stimulate receptor autophosphorylation by $6.8 \pm 0.6$ and $6.6 \pm 0.5$ fold, respectively $(n=6)$ (mean $\pm \mathrm{SD})$.

\section{Discussion}

We studied the effect of rat amylin, amidated at the carboxy-terminus, on in vivo insulin action in conscious rats, by the hyperinsulinaemic, euglycaemic clamp technique, in combination with a continuous infusion of $\left[3-{ }^{3} \mathrm{H}\right]$-glu- cose. This method is considered to be the most suited for measurement of in vivo insulin action [19]. Our experiments describe an in vivo effect of amylin on glucose homeostasis by antagonizing insulin action on both peripheral tissues and liver. This is in agreement with the clamp experiments of Molina et al. [8] who showed that human amylin induced peripheral and hepatic insulin resistance in anaesthetized rats. In addition, the use of two different amylin infusion rates during the clamp, enabled us to show that hepatic glucose production is more sensitive to the action of amylin than peripheral tissue glucose uptake. To our knowledge, no other studies have been performed which have quantitated the antagonizing effect of amylin on insulin-inhibited hepatic glucose production and insulin-stimulated peripheral glucose uptake. A study by Bretherton-Watt et al. [6], using the intravenous glucose tolerance test in man, suggested that amylin may not have an important role in carbohydrate metabolism. However, during glucose tolerance tests it is difficult to quantitate subtle changes in insulin action [19] and the amylin infusion period may have been too short to reach an effect on insulin-mediated glucose metabolism. During our rat experiments it took 30 min and during dog experiments [7] 30-60 min, before any effect of amylin on plasma glucose level was detected. During human studies therefore, an even longer amylin-infusion period may be necessary for initiation of amylin action or for achievement of full amylin action.

Basal rat plasma amylin levels were $60 \pm 20 \mathrm{pmol} / 1$, or after an $18 \mathrm{~h}$ fast, below the detection limit of the RIA, except for two rats having $75 \mathrm{pmol} / \mathrm{l}$, suggesting that amylin can be considered as a peptide which appears under normal conditions in the peripheral circulation of the rat. Applied plasma amylin levels of $220 \pm 75 \mathrm{pmol} / 1$, an approximate four-fold increase over basal amylin levels, antagonized insulin action on the liver, resulting in a $100 \%$ increase of hepatic glucose output. Amylin levels of $4750 \pm 750 \mathrm{pmol} / \mathrm{l}$ induced a $250 \%$ increase of insulin-inhibited hepatic glucose output and, in addition, a $30 \%$ decrease of insulin-stimulated peripheral glucose uptake. During our hyperinsulinaemic clamp study, the molar ratio between plasma amylin and insulin was 1:5 at the low amylin infusion rate and 5:1 at the high amylin infusion rate. The low ratio of plasma amylin relative to plasma insulin (1:5) might be achieved under pathological conditions, since it is known that under normal basal physiological conditions the ratio between plasma amylin and insulin is in the range of $1: 15$ [20] to $1: 25$ [21] for humans. Furthermore, the pancreatic production of amylin relative to insulin is in the range of $1: 3$ or $1: 10$ for rats [22, 23] to $1: 100$ for humans [24] and to this ratio the liver is exposed. This is particularly important since we have shown that when the liver is exposed, under hyperinsulinaemic conditions, to a 1:5 molar ratio of amylin relative to insulin, hepatic glucose production increases while no effect is detected on peripheral glucose uptake. Finally, it remains to be established whether amylin, at physiological concentrations influences carbohydrate metabolism and whether this requires long-term amylin infusion.

Since amylin is synthetized in the Beta cells of the islets of Langerhans [24] and secreted into the bloodstream [20, 
21], relatively high concentrations of this polypeptide are expected to appear in the vascular portal system. In addition, our data show that the liver is more sensitive to amylin than peripheral tissues, suggesting that the liver may be the predominant organ regulated by this hormone in vivo. The clamp experiments were performed using rats fasted for $18 \mathrm{~h}$ so that the livers were depleted of glycogen [25]. The increased hepatic glucose production in response to amylin suggests that gluconeogenesis is a main pathway affected by the peptide and responsible for the enhanced glucose production.

The effect of amylin on glucose homeostasis can be explained by a direct antagonism of insulin action on peripheral tissues and liver. Alternative explanations could, however, be that amylin acts indirectly, by inducing changes in blood flow or by inducing increases in plasma levels of hormones which counterregulate insulin action, i. e. glucagon, epinephrine, norepinephrine, and corticosterone, or that amylin decreases insulin concentrations in the blood, e. g. by enhancing insulin's metabolic clearance rate. With respect to blood flow, this possibility cannot be excluded. However, this explanation seems unlikely since James et al. [26] have shown that blood flow is not a major determinant of insulin-mediated glucose uptake in muscle of rats, as studied by means of the hyperinsulinaemic euglycaemic clamp technique. Unfortunately, the effect of blood flow on hepatic glucose production was not investigated. Our data exclude the possibility that amylin acts indirectly by degrading insulin or by induction of insulin antagonizing hormones. In addition, Cooper et al. $[4,5]$ have shown that amylin antagonizes insulin action in vitro on isolated muscles, also indicating a direct effect. Our in vitro insulin-receptor studies are not in favour of a direct interference of amylin on insulin binding and insulinstimulated receptor autophosphorylation. This suggests that amylin may act via its own receptor and interferes with post-receptor processes of the insulin receptor. It is remarkable that insulin target tissues other than muscle and liver, like fat (i.e. adipocytes), do not become insulin resistant in response to amylin [5].

The overall half-life of amylin in the rat was $9.4 \pm 1 \mathrm{~min}$, which is in agreement with the data of Bretherton-Watt et al. [6] performed in man $(11.8 \pm 0.9 \mathrm{~min})$. The metabolic clearance rate (MCR) of amylin in the rat (26$\left.55 \mathrm{ml} \cdot \mathrm{min}^{-1}\right)$ is $4-9$ fold higher than the MCR of insulin $\left(6 \mathrm{ml} \cdot \mathrm{min}^{-1}\right)$ found in our rat study. However, during infusion a certain fraction of amylin may stick to the plastic tubing [6] and our calculated MCR for amylin might therefore be overestimated. With this reservation in mind, the data indicate that amylin is a peptide which exhibits a high turn-over rate and suggest that one or more tissues have a high capacity for amylin removal from the plasma.

In summary, the observed effects of amylin strengthen the hypothesis that amylin is a newly recognized pancreatic hormone which antagonizes insulin action. An increased secretion of this peptide has the potential to play a role in the development of insulin resistant states and hyperglycaemia as seen in patients with Type 2 diabetes.

Acknowledgements. We thank Drs. R.A.Amons for performing amino acid sequencing, D. Kalsbeek for corticosterone determina- tions and C. J.M. Lips for his interest and coordinating role. Technical assistance by H.C.M.Sips is greatly acknowledged. This work was supported by a grant from the Dutch Diabetes Research Foundation.

\section{References}

1. Westermark P, Wernstedt C, Wilander E, Sletten K (1986) A novel peptide in the calcitonin gene related peptide family as an amyloid fibril protein in the endocrine pancreas. Biochem Biophys Res Commun 140: 827-831

2. Westermark P, Wernstedt C, Wilander E, Hayden DW, O'Brien TD, Johnson KH (1987) Amyloid fibrils in human insulinoma and islets of Langerhans in the diabetic cat are derived from a novel neuropeptide-like protein also present in normal islet cells. Proc Natl Acad Sci USA 84: 3881-3885

3. Cooper GJS, Willis AC, Clark A, Turner RC, Sim RB, Reid KBM (1987) Purification and characterization of a peptide from amyloid-rich pancreases of type 2 diabetic patients. Proc Natl Acad Sci USA 84: 8628-8632

4. Leighton B, Cooper GJS (1988) Pancreatic amylin and calcitonin gene-related peptide cause resistance to insulin in skeletal muscle in vitro. Nature 335: 632-635

5. Cooper GJS, Leighton B, Dimitriadis GD et al. (1988) Amylin found in amyloid deposits in human type 2 diabetes mellitus may be a hormone that regulates glycogen metabolism in skeletal muscle. Proc Natl Acad Sci USA 85: 7763-7766

6. Bretherton-Watt D, Gilbey SG, Ghatei MA, Beacham J, Bloom SR (1990) Failure to establish islet amyloid polypeptide (amylin) as a circulating Beta cell inhibiting hormone in man. Diabetologia 33: $115-117$

7. Sowa R, Sanke T, Hirayama J, Tabata H, Furuta H, Nishimura S, Nanjo K (1990) Islet amyloid polypeptide amide causes peripheral insulin resistance in vivo in dogs. Diabetologia 33: 118-120

8. Molina JM, Cooper GJS, Leighton B. Olefsky JM (1990) Induction of insulin resistance in vivo by amylin and calcitonin gene-related peptide. Diabetes 39: 260-265

9. Young DA, Deems RO, Deacon RW, McIntosh RH, Foley JE (1990) Effects of amylin on glucose metabolism and glycogenolysis in vivo and in vitro. Am J Physiol 259: E457-E461

10. Roberts AN, Leighton B, Todd JA et al. (1989) Molecular and functional characterization of amylin, a peptide associated with type 2 diabetes mellitus. Proc Natl Acad Sci USA 86: 9662-9666

11. Steffens $A B$ (1969) A method for frequent sampling of blood and continuous infusion of fluids in the rat without disturbing the animal. Physiol Behav 4: 833-836

12. Vink PC, Roelfsema F (1981) A new swivel for double infusion of fluids into rats. Physiol Behav 27: 175-177

13. Doberne L, Greenfield MS, Schulz B, Reaven GM (1981) Enhanced glucose utilization during prolonged glucose clamp studies. Diabetes 30: 829-835

14. Koopmans SJ, Sips HCM, Bosman J, Radder JK, Krans HMJ (1989) Antilipolytic action of insulin in adipocytes from starved and diabetic rats during adenosine-controlled incubations. Endocrinology 125: 3044-3050

15. Gugten J van der, Slangen JL (1977) Release of endogenous catecholamines from rat hypothalamus related to feeding and other behaviors. Pharmacol Biochem Behav 7: 211-215

16. Murphy BEP (1967) Some studies of the protein-binding of steroids and their application to the routine micro- and ultramicro measurement of various steroids in body fluids by competitive protein-binding radio assay. J Clin Endocrinol Metab 27: 973983

17. Klinkhamer MP, Groen NA, Zon GCM van der et al. (1989) A leucine-to-proline mutation in the insulin receptor in a family with insulin resistance. EMBO 8: 2503-2507

18. Maassen JA, Klinkhamer MP, Odink RJH et al. (1988) Improper expression of insulin receptors on fibroblasts from a leprechaun patient. Eur J Biochem 172: 725-729 
19. Bergman RN, Finegood DT, Ader M (1985) Assessment of insulin sensitivity in vivo. Endocr Rev $6: 45-86$

20. Mitsukawa T, Takemura J, Asai J, Nakazato M, Kangawa K, Matsuo H, Matsukura S (1990) Islet amyloid polypeptide response to glucose, insulin, and somatostatin analogue administration. Diabetes 39: 639-642

21. Butler PC, Chou J, Carter WB, Wang YN, Bu BH, Chang JK, Rizza RA (1990) Effects of meal ingestion on plasma anylin concentrations in NIDDM and nondiabetic humans. Diabetes 39 : $752-756$

22. Ogawa A, Harris V, McCorkle SK, Unger RH, Luskey KL (1990) Amylin secretion from the rat pancreas and its selective loss after streptozotocin treatment. J Clin Invest 85: 973-976

23. Fehmann HC, Weber V, Göke R, Göke B, Arnold R (1990) Cosecretion of amylin and insulin from isolated rat pancreas. FEBS 262: 279-281

24. Kahn SE, D'alessio DA, Schwartz MW, Fujimoto WY, Ensinck JW, Taborsky GJ Jr, Porte D Jr (1990) Evidence of cosecretion of islet amyloid polypeptide and insulin by $\beta$-cells. Diabetes 39 : 634-638
25. Smith D, Rossetti L, Ferrannini E et al. (1987) In vivo glucose metabolism in the awake rat: tracer and insulin clamp studies. Metabolism 36: 1167-1174

26. James DE, Burleigh KM, Storlien LH, Bennett SP, Kraegen EW (1986) Heterogeneity of insulin action in muscle: influence of blood flow. Am J Physiol 251: E422-E430

Received: 27 April 1990

and in revised form: 23 November 1990

Dr.S.J.Koopmans

Department of Endocrinology and Metabolic Diseases

University Hospital

Building 1 C4R82

Rijnsburgerweg 10

NL-2333 AA Leiden

The Netherlands 